\title{
REFLEKSJE NAD BADANIAMI MYŚLI POLITYCZNEJ W POLSCE Z UWZGLĘDNIENIEM TENDENCJI W WYBRANYCH KRAJACH ANGLOSASKICH. OD DELIMITACJI POJĘĆ DO ASPEKTÓW METODOLOGICZNYCH
}

\author{
REFLECTIONS ON THE STUDY OF POLITICAL THOUGHT IN \\ POLAND WITH A CONSIDERATION OF TRENDS IN SELECTED \\ ANGLO-SAXON COUNTRIES: FROM DELIMITATION OF \\ CONCEPTS TO METHODOLOGICAL ASPECTS
}

Grzegorz Radomski* $\odot$, Patryk Tomaszewski** ๑

\section{- ABSTRAKT}

Autorzy ukazują obszary badań z zakresu myśli politycznej analizowane przez polskich naukowców. Szukają przy tym odpowiedzi na pytanie, czy polskie badania nad myślą polityczną odbiegają od trendów prezentowanych w krajach anglosaskich. Artykuł ukazuje różnorakie spojrzenia na samą definicję myśli politycznej i kategorii pokrewnych, jak doktryna czy też ideologia. Analizując różne ujęcia badań nad myślą polityczną w Polsce, autorzy starają się odpowiedzieć na pytanie, czy możliwe jest uporządkowanie metod i technik badawczych na tyle, aby stanowily uniwersalny model, którym mogą się posługiwać badacze. W polskim
The authors present areas of research on political thought undertaken by Polish researchers. They seek an answer to the question whether the Polish research on political thought differs from trends presented in Anglo-Saxon countries. The article offers a different perspective on the very definition of political thought and related categories, such as doctrine or ideology. Analyzing various approaches to the study of political thought in Poland, the authors seek to answer the question of whether it is possible to organize research methods and techniques in such a way that they constitute a universal model that can be used by researchers. In the Polish scientific discourse,

* Uniwersytet Mikołaja Kopernika w Toruniu, Wydział Nauk o Polityce i Bezpieczeństwie.

** Uniwersytet Mikołaja Kopernika w Toruniu, Wydział Nauk o Polityce i Bezpieczeństwie. 
dyskursie naukowym w ostatnich latach mocno zaznacza się potrzebę wypracowania takich metod w obszarze nauk społecznych, które pozwolą unikać interpretacjonizmu. W artykule przyjrzano się wybranej i ograniczonej liczbie publikacji z obszaru badań nad myślą polityczną i ideologią w krajach anglosaskich, aby porównać, z jakimi problemami badawczymi mierzą się naukowcy w Wielkiej Brytanii czy też w USA. Autorzy zaprezentowali własną propozycję konceptualizacji w ujęciu linearnym etapów myślenia politycznego. W podsumowaniu stwierdzili, że odnosząc się do treści artykułów naukowych, można dostrzec podobieństwo analizowanych problemów zarówno w Polsce, jak i w krajach anglosaskich. Skonkludowali, że nie istnieje uniwersalny model badań myśli politycznej. Zdaniem autorów w Polsce nadal będzie się toczyła dyskusja na temat przedmiotu zainteresowania myśli politycznej, a także będą trwały poszukiwania definicji odróżniającej myśl polityczną od ideologii i doktryny politycznej.

Słowa kluczowe: polska myśl polityczna; metodologia; doktryny polityczne; ideologia polityczna the need to develop such methods in the field of social sciences, which would avoid subjective interpretations, has been strongly emphasized in recent years. The article examines a selected and limited number of publications on political thought and ideology in Anglo-Saxon countries, in order to compare the research problems faced by scholars in Great Britain or the USA. The authors of the paper present their own proposal of linear conceptualization of the stages of political thought. In conclusion, the authors state that referring to the content of scientific articles, one can notice the similarity of the analyzed problems both in Poland and in Anglo-Saxon countries. They conclude that there is no universal model for the study of political thought. According to the authors, there will still be a discussion in Poland on the subject of political thought, as well as the search for a definition that distinguishes political thought, ideology and political doctrines.

Keywords: Polish political thought; methodology; political doctrines; political ideology

\section{WPROWADZENIE}

Celem niniejszego artykułu jest zaprezentowanie obszarów badań polskich naukowców zajmujących się zagadnieniami z zakresu myśli politycznej i wskazanie najważniejszych problemów, na jakie natrafiają. Są to przede wszystkim problemy dotyczące zdefiniowania obszarów badań, przedmiotu zainteresowań, kategoryzacji pojęć, a także stosowanych metod i technik badawczych. Ponadto autorzy postanowili zestawić polskie badania z zakresu myśli politycznej z anglosaskimi tendencjami badawczymi. Zestawienie to pozwoli odpowiedzieć na pytanie, na ile polskie badania nad myślą polityczną pokrywają się z popularnymi kierunkami badań światowych w tym obszarze. Autorzy sformułowali hipotezę, że widoczna jest adaptacja anglosaskich rozwiązań metodologicznych z podkreśleniem konieczności uwzględnienia odrębności polskiej myśli politycznej. Druga zaś hipoteza mówi o tym, że mimo starań wielu badaczy nie udało się 
w Polsce stworzyć zamkniętego katalogu tematów badawczych z obszaru myśli politycznej, a także wypracować katalogu metod badawczych, mających cechy ontologicznej spójności, a pozbawionych interpretacjonizmu (Bachryj-Krzywaźnia, 2016, s. 7-23).

Artykuł stanowi autorską analizę problemów badawczych poruszanych przez naukowców zajmujących się badaniem myśli politycznej.

Metoda badawcza zastosowana w pracy to przede wszystkim analiza treści (Ścigaj, Bukowski, 2012; Szczepaniak, 2012, s. 89; Bajer, 2012, ss. 15-48), ponadto zastosowano technikę komparatystyczną, która skupia się na konfiguracjach podobieństw lub różnic w ograniczonym zakresie przypadków (Bajer, 2012, ss. 15-48).

\section{PODSTAWOWE ZAŁOŻENIA BADAŃ POLSKIEJ MYŚLI POLITYCZNEJ}

W badaniach nad myślą polityczną w Polsce można dostrzec trzy podstawowe założenia, które od lat siedemdziesiątych XX wieku określają pole dyskursu na temat myśli politycznej.

Po pierwsze niemożliwe jest opracowanie jednej akceptowanej przez wszystkich badaczy definicji myśli politycznej. Wychodząc z takiego założenia, Marek Sobolewski zasugerował rezygnację z definiowania myśli politycznej, uznając takie rozważania za nieprzynoszące pożytku. Propozycja zgłoszona przez Sobolewskiego (Sobolewski, 1976, ss. 3-17) dość szybko została jednak odrzucona. Już w latach siedemdziesiątych postulowano, aby uczynić $\mathrm{z}$ pojęcia myśli politycznej przedmiot refleksji. Wiązano to także z próbą odejścia od wpisywania tej kategorii w ciąg logiczny obok doktryny czy idei. Badacze uznawali wręcz określenie zakresu myśli politycznej za swój obowiązek, co doprowadziło do szeregu autorskich ujęć utrwalających stan nieokreśloności pojęcia. Często posługiwano się formułą definicji klasycznej: Definitio fit per genus proximum et differentiam specificam - „definicja powstaje przez rodzaj najbliższy i różnicę gatunkową" (Maj, 2020, s. 35-37). Dążąc do stworzenia definicji realnej, a nie tylko nominalnej, wskazuje się niejednokrotnie, że nie jeden składnik, ale wiązka/ rodzina własności może wyznaczyć jej istotę (Woźniak, 2015). Dysfunkcjonalność polegająca na braku zgody co do istoty pojęcia nie jest traktowana jako wada, lecz jako potencjalna możliwość rozwoju dyscypliny. Nie dostrzega się raczej, że przyjęta strategia badawcza wpływa na wyniki. Jedyna znana polemika - między Waldemarem Paruchem a Krzysztofem Kawalcem, dotycząca 
pracy tego ostatniego - nie stała się zarzewiem szerszej dyskusji w środowisku ${ }^{1}$. Sporadycznie wskazywano, że „badacz myśli politycznej powinien koncentrować swoją uwagę na dokonywaniu analizy kazualno-nomologicznej, poszukiwaniu jednoznacznych związków typu programowo-genetycznego oraz praw, prawidłowości, zależności synchronicznych i diachronicznych" (Ponczek, 2015, s. 128). Zasadniczo poza środowiskiem politologów nadal nie dostrzega się potrzeby zdefiniowania pojęcia, stosując dowolną jego interpretację (Bäcker, 2017, ss. 125-142; Ponczek, 2015, s. 121). Posługiwano się zatem często definicjami myśli politycznej o szeroko zakreślonym polu, a także przedmiocie i podmiocie badawczym.

Nierzadko też pojęcie myśli politycznej jest traktowane synonimicznie z pojęciem filozofii politycznej, szczególnie jeśli badaniami zajmują się filozofowie polityki. W kręgu badaczy prawa dyskusje toczą się wokół takich pojęć, jak doktryna i ideologia. Recepcja rozróżnienia dokonanego przez Leo Straussa obecna jest w stosunkowo niewielu opracowaniach. Wprawdzie stanowi punkt odniesienia dla wielu badaczy, ale nie jest w pełni akceptowana. Trudności z definiowaniem pojęcia spowodowały, że prób jego delimitacji brakuje w wielu kompendiach czy słownikach. Zdarza się również, że autorzy opracowań poświęconych doktrynom politycznym nie wyjaśniają zakresu pojęcia myśli politycznej, stosując je jako synonim doktryny politycznej, które to ujęcie starają się zoperacjonalizować. Przykładowo uczynił tak Andrzej Sylwestrzak, nadając jednemu z rozdziałów swego podręcznika tytuł „Myśl polityczna starożytności”, a nie wyjaśniając tego pojęcia (Sylwestrzak, 1994, s. 20). Zdefiniowania myśli politycznej nie podjął się również Grzegorz Kucharczyk w pracy Polska myśl polityczna po roku 1939 (Kucharczyk, 2009).

Po drugie zwraca się uwagę na konieczność opracowania metod badania myśli politycznej (Jajecznik, 2006, ss. 255-256; Paruch, 2015, ss. 157-175). Przykładem może być propozycja zastosowania kwestionariusza pytań badawczych. W tym celu niezbędne jest przystosowanie ogólnych zasad konstrukcji, np. różnych skal, do potrzeb analizy myśli politycznej (Jajecznik, 2006, s. 257). Pojawiają się też próby przeniesienia na grunt polski ilościowej techniki (Comparative Manifesto Project) opracowanej w latach osiemdziesiątych do badań nad programami

1 W artykule z 1999 roku Paruch zauważył, że „Nie ma w rozważaniach metodologicznych o myśli politycznej zgodności w dwóch kwestiach: (1) co do znaczenia i pojemności tego terminu oraz (2) konieczności definiowania takich pojęć, jak ideologia, doktryna czy program, określanie ich zakresów oraz wyznaczanie granic je oddzielających" (Paruch, 1999, s. 32-33). 
politycznymi, które bez wątpienia stanowią odzwierciedlenie myśli politycznej wyrażanej przez dane ugrupowanie. Jednak technika ilościowa, jak zauważył Wojciech Woźniak, ma pewne wady. „Do najpoważniejszych mankamentów tego podejścia należy [...] wciąż arbitralny sposób kodowania materiału źródłowego oraz brak kontekstualizacji danych do sytuacji ideowo-politycznej w poszczególnych krajach" (Woźniak, 2017, s. 46). Bez wątpienia jednak zaczęła się zmieniać samoświadomość środowiska politologów dotycząca własnej kultury metodologicznej.

Po trzecie akceptowany jest pogląd Isaiaha Berlina, który pisał: „zaniedbywanie dziedziny myśli politycznej z tego względu, że jej nie dość wyraźnie określony przedmiot o określonych konturach jest nieuchwytny dla sztywnych abstrakcyjnych modeli oraz precyzyjnych narzędzi przydatnych w analizie logicznej lub językowej, domaganie się jednolitej metody w filozofii i odrzucanie wszystkiego, z czym metoda ta nie daje sobie rady - prowadzi jedynie do sytuacji, w której zdani jesteśmy na łaskę prymitywnych i bezkrytycznych przekonań politycznych" (Berlin, 1991, s. 110-111; Król, 2008, ss. 58-59).

\section{DEFINIOWANIE MYŚLI POLITYCZNEJ}

W ujęciu chronologicznym jedną z pierwszych definicji myśli politycznej zaprezentował prawnik i politolog Kazimierz Opałek w 1962 roku. Jego zdaniem myśl polityczna „to koncepcje gruntujące, uzasadniające i projektujące działalność w dziedzinie polityki wewnętrznej i zewnętrznej danego państwa, stanowiące bądź prywatne opinie, bądź oficjalne doktryny ugrupowań i stronnictw" (Opałek, 1962, s. 320). Wyraźne skupienie się na państwie jako podmiocie polityki dostrzegalne jest w ujęciach innych badaczy wywodzących się ze środowiska prawników, jak chociażby Grzegorza Seidlera (Seidler, 1974, s. 8). Również współcześnie część politologów posługuje się pojęciem myśli polityczno-prawnej. Takie ujęcie wpływało także na określenie kategorii źródeł do badania. Dominowało przekonanie o konieczności oparcia analizy na traktatach politycznych. Jak sformułował to Jan Baszkiewicz: „wielka konwersacja toczona przez wieki w gronie tytanów intelektu" (Chojnacki, Olszewski, 2004, s. 11).

W konsekwencji można wyróżnić dwa sposoby definiowania pojęcia przez badaczy: o zakresie „węższym” i „szerszym”.

Henryk Zieliński, który zapoczątkował badania w tym obszarze w latach siedemdziesiątych, zdefiniował myśl polityczną jako „wskazania o charakterze 
generalnym, determinujące podstawowe kierunki rozwoju narodu i państwa i przejawiające się w działalności politycznej w sposób względnie trwały" (Zieliński, 1975, s. 14).

Podobnie zdaniem Jana Jachymka myśl polityczna to „poglądy oraz koncepcje afirmujące, reformujące bądź negujące ustrój polityczny państwa, a także tworzące wizję nowego ładu społecznego" (Jachymek, 1982, s. 3). Nieco szerzej zdefiniował to pojęcie Edward Olszewski. Według niego są to „idee dotyczące człowieka, jako istoty politycznej, jego miejsca w systemie politycznym, wyobrażeń odnoszących się do organizacji społeczeństwa, państwa, prawa, roli jednostek, dróg przeobrażeń społeczeństwa, polityki i jej związków z innymi dziedzinami życia społecznego, ekonomicznego, intelektualnego" (Olszewski, 1999, s. 194; Olszewski, 2015, ss. 154-173). Bliski takiemu ujęciu jest również Andrzej Friszke, zdaniem którego myśl polityczna to „nie tylko namysł nad kategoriami polityki, narodu, państwa, demokracji itp., ale także diagnoza sytuacji politycznej, uzasadnienie zajmowanego stanowiska, zastanawianie się nad możliwościami zmiany konfiguracji międzynarodowej, szukanie możliwości zmiany sytuacji w Polsce i wskazanie czynników zmianę tę przyspieszających" (Friszke, 1995, s. 6). Również Jerzy Kornaś uznał, że są to jedynie koncepcje, które charakteryzują się dużym stopniem generalizacji i systematyzacji założeń oraz zasad (Kornaś, 1995, s. 7). Mariusz Żychowski odwołał się do koncepcji o dość szerokim zakresie: teoretycznym, ideologicznym i politycznym (Żychowski, 1976, s. 7). W tym nurcie mieści się także propozycja Michała Śliwy, który zauważył, że: „W zakresie przedmiotu myśli politycznej sytuować się będzie również działalność ideotwórcza i doktrynotwórcza danego myśliciela i pisarza politycznego, ugrupowań politycznych i instytucji władzy, grup i organizacji społecznych, elit politycznych itp. Węzłowym problemem myśli politycznej będzie zagadnienie polityki, czyli sfery rzeczywistości politycznej, która związana jest ze sprawowaniem władzy" (Śliwa, 1993, s. 6).

Drugi nurt w definiowaniu myśli politycznej został szeroko zakrojony. Zdaniem Waldemara Parucha myśl polityczna oznacza wszelką formę refleksji nad rzeczywistością polityczną, niezależnie od stopnia rozwoju, wewnętrznej spójności i systematyzacji oraz uteoeryzowania i konkretyzacji” (Paruch, 1999, s. 36; Paruch, 2005, s. 10). Ten ostatni badacz skonstatował, że w rozważaniach na temat myśli politycznej widoczne są dwa stanowiska. Pierwsze z nich nadaje myśli politycznej samodzielny i maksymalnie szeroki zakres znaczeniowy. Wówczas mówimy o subkategorii z obszaru świadomości politycznej, której zdefiniowanie jest niezależne od definicji innych pojęć umieszczanych w tym samym ciągu 
znaczeniowym (ideologia, doktryna, koncepcja, program, idea). Drugi pogląd mówi o odniesieniu myśli politycznej do kategorii sprawowania władzy, a więc „Zgodnie z nim w zakresie myśli politycznej mieszczą się wszystkie poglądy, których przedmiotem jest zagadnienie polityki” (Paruch, 1999, ss. 32-34).

Odniesieniem dla twórców myśli politycznej jest zawsze rzeczywistość polityczna postrzegana poprzez ujęcie deskrypcyjne, eksplanacyjne, interpretacyjne, ewaluacyjne, prognostyczne czy projekcyjne. Istotę myśli politycznej $\mathrm{w}$ takim ujęciu stanowi wizja idealnego ładu, która powstaje $\mathrm{z}$ inspiracji i w konfrontacji z obserwowaną i subiektywnie opisywaną rzeczywistością, składającą się z działań politycznych podejmowanych przez podmioty polityki oraz z procesów politycznych przez nie zapoczątkowanych. Podobne ujęcie zaprezentowała Ewa Maj. Zdaniem badaczki myśl polityczna jest „społecznie i historycznie uwarunkowana, wyrastająca w określonym systemie wartości, ogólna projekcja rzeczywistości politycznej (zarówno przeszłej, teraźniejszej, jak i przyszłej) o wysokim stopniu wewnętrznej koherencji, chociaż dopuszczająca niewielkie odmienności interpretacyjne i zmienność w sekwencjach czasowych, ale nienaruszająca przyjętego systemu aksjologicznego" (Maj, 2000, s. 12). Wspomniana autorka w innej publikacji doprecyzowała, że myśl polityczna zawiera refleksje nad polityką. Obejmuje kwestie wartości politycznych, celów politycznych, wzorców postaw, stylów myślenia i zachowania politycznego. Mieści w sobie analizę zagadnień społecznych, politycznych, gospodarczych, kulturalnych (Maj, Wójcik, 2008, s. 7). Starając się określić zakres pojęcia w politologii, Ryszard Skarzyński stwierdził, że myśl polityczna zajmuje się „, badaniem ideologii pod kątem ich powstawania, rozwoju i upadku oraz relacji, w jakich pozostają do innych światów myślowych, przede wszystkim programów politycznych" (Skarzyński, 2004, s. 98). Trochę szerszy zakres określił Marcin Król, którego zdaniem myśl polityczna: „Obejmuje swoimi zainteresowaniami wszystkie publiczne zachowania jednostek i grup społecznych, które w jakikolwiek sposób odnoszą się do wzajemnych relacji między tymi jednostkami i grupami oraz do wytworów ich działań" (Król, 1998, s. 5). Podobnie szeroko określił ramy myśli politycznej toruński badacz Andrzej Zybertowicz, według którego są to wszystkie pojęciowe wypowiedzi dotyczące sfery polityki (Zybertowicz, 1990, s. 10). W takich ujęciach marginalizowane są przez badaczy kryteria podmiotowe oraz ustrukturyzowanie. Tak rozumiana myśl polityczna ma cztery zakresy: pragmatyczny, socjologiczny, filozoficzny i kulturowy (Paruch, 1999, ss. 36-37). W szeroki sposób pojęcie zdefiniował Bartosz Smolik, którego zdaniem tytułowa kategoria odnosi się do „wszelkich 
przemyśleń dotyczących zjawisk o charakterze makrospołecznym, w sposób pośredni lub bezpośredni wiążących się ze sferą polityczności” (Smolik, 2004, s. 8).W wielu ujęciach podkreślana jest waga założeń aksjologicznych. Andrzej Feliks Grabski, definiując myśl polityczną jako refleksję o nieprzypadkowej zmienności rzeczywistości politycznej, dodawał, że bez aksjologii nie może się obyć żadna myśl polityczna (Grabski, 1983, ss. 53-57). Autorzy podkreślają, że to, co polityczne, powstaje w wyniku konfliktu (Skarzyński, 1990, ss. 7-32; Skarzyński, 1992, ss. 107-119).

Badacze sporadycznie ukazują stadia rozwojowe myśli politycznej. Uczynił to Władysław Kulesza, który wyróżnił następujące etapy: pierwszy to pewne spostrzeżenia, hasła, pomysły oraz odrębne postulaty ujęte w sposób prosty, wręcz zdroworozsądkowy; drugi etap to układanie się elementów pierwotnych w umysłach zwolenników w pewne całości, nazywane koncepcjami, w których dostrzegamy pewien ład; trzeci etap to koncepcje polityczne, które stają się podstawą do tworzenia rozmaitych form myśli politycznej typu: ideologia, doktryna i programy polityczne (Kulesza, 1996, s. 8).

Odpowiedź na pytanie o sposób rozumienia pojęcia myśli politycznej można prześledzić na poziome pragmatycznym (Paruch, 2006, ss. 207-214). Wprawdzie trudno określić liczbę prac poświęconych myśli politycznej, ale na podstawie analizy rekordów biblioteki Uniwersytetu Warszawskiego można przyjąć, że jest ich około 2700 tytułów, w których pojawia się wyrażenie myśl polityczna, część z tych rekordów (ok. 700) dotyczy sytuacji, gdy wydawcą jest instytucja (czasami dotyczy serii wydawniczej) zawierająca w nazwie hasło 'myśl polityczna'. Jest to tylko liczba orientacyjna, zagadnienie myśli politycznej jest bowiem obecne w pracach, których tytuły nie odnoszą się do tej kategorii lub np. zawierają określenie 'myślenie polityczne' (Rogowski, 2013). Należy jednak pamiętać, że proponowane przez autorów wygodne idealizacje wpływają niejednokrotnie na poziom komunikowalności. Oznacza to, że tytuł sygnalizuje więcej niż treść pracy (Woźniak, 2015, s. 142).

W konsekwencji w pracach badawczych polskich autorów przeważają następujące zagadnienia:

- myśl polityczna wybranych twórców;

- myśl polityczna wybranych nurtów politycznych;

- myśl polityczna partii politycznych;

- zagadnienia problemowe - np. samorząd, racja stanu, demokracja, bezpieczeństwo, polityka zagraniczna. 
Należy jednak zgodzić się z opinią Waldemara Parucha, że obecnie nie dominuje już ujęcie idiograficzne i deskryptywne (Paruch, 2009, s. 38). W monografiach i artykułach przeważa badanie działalności ideotwórczej, stylu myślenia politycznego czy tożsamości danego podmiotu. Wyjątkowo podejmowane są próby określenia zagadnień, które nie będą podlegały analizie, nie mieszczą się bowiem w zakresie związanym z przedmiotowym ujęciem myśli politycznej (Paszkowska, 2015, s. 103).

Konsekwencją różnych prób definiowania myśli politycznej był i jest różny sposób określenia pojęcia myśli politycznej w odniesieniu do pokrewnych pojęć. W przypadku drugiej grupy definicji (szerokie ujęcie) myśl polityczną zdecydowanie traktowano jako nadrzędną, wpisując ją w ciąg: myśl polityczna - ideologia - doktryna - program polityczny. Najpełniej pogląd ten zwerbalizował Waldemar Paruch, stwierdzając: „nadrzędność myśli politycznej nad teorią polityczną, koncepcją/doktryną i programem. Tym samym wszelkie badania doktryn politycznych i teorii politycznej są fragmentem refleksji o myśli politycznej, gdyż zakres tego pojęcia obejmuje rozważania o charakterze politycznym, ideologicznym, koncepcyjno-doktrynalnym i pragmatycznym” (Paruch, 2015, s. 160). Wśród badaczy definiujących myśl polityczną „wąsko” zaznaczyły się różne stanowiska. Część uznawała myśl polityczną za nieuformowaną ideologię, tworząc następujący schemat zależności: ideologia - myśl polityczna - doktryna - program polityczny. Natomiast Aleksander Łuczak stwierdził, że myśl polityczna jest odmienna od doktryny i powinna być badana odrębnie. Kamil Różewicz wpisał ją w ciąg: ideologia - myśl polityczna - doktryna, co oznacza, że stanowi ona stadium pośrednie między ideologią a programem, nazwę dla „pomysłów i poglądów, które jeszcze ideologią polityczną nie są, ale są już więcej niż doraźnym programem”. Jeszcze inaczej problem ten ujął Tadeusz Klementewicz, który usytuował zainteresowanie myślą polityczną w obszarze badań dotyczących form kultury świadomości uczestników polityki (Klementewicz, 2013, s. 32). Zdaniem Bronisława Pasierba z myślą polityczną wiążą się takie pojęcia, jak ideologia, doktryna, program polityczny, ale także światopogląd, mit, utopia oraz symbol w polityce (Pasierb, 1996, s. 8-11).

Warto w tym miejscu zwrócić uwagę na warszawską szkołę historii idei. Jednym $\mathrm{z}$ inicjatorów tego nurtu był Bronisław Baczko. Trudno wskazać paradygmat obecny w badaniach przedstawicieli tej szkoły, ale najczęściej podkreśla się ich kontekstualność, interdyscyplinarność, antropologiczne podejście oraz zainteresowanie ciągłością idei. Pewną rolę odgrywały też inspiracje marksi- 
stowskie. Był to oryginalny wkład Polaków w szeroko rozumiane badania historii intelektualnej (Koepke, 2005, s. 259-276)2.

Z zaprezentowanego przeglądu wynika, że badacze w Polsce nie posługują się jedną definicją myśli politycznej. Nie dokonano też pełnej delimitacji problemów badawczych, jakie należałoby analizować. Trudno odnaleźć odpowiedź na pytanie, gdzie przebiega granica między ideologią, doktryną polityczną i myślą polityczną. Można zauważyć, że badacze nie są również zgodni co do definiowania takich kategorii, jak ideologia czy doktryna. Świat idei ${ }^{3}$ jest analizowany zarówno przez filozofów, politologów, jak i historyków idei. W przetłumaczonej na język polski książce Andrew Heywooda Ideologie polityczne. Wprowadzenie autor napisał: „Idee polityczne nie są jedynie bowiem biernym odbiciem nabytych interesów czy osobistych ambicji, ale mają także potencjał do inspirowania i kierowania działalnością polityczną jako taką, a zatem kształtować życie materialne. Jednocześnie idee polityczne nie powstają w próżni: nie spadają $z$ nieba niczym deszcz. Wszystkie one są kształtowane przez warunki społeczne i historyczne, w których się rozwijają, a także przez ambicje polityczne, którym służą. Mówiąc wprost: teoria i praktyka polityczna są ze sobą nierozerwanie związane" (Heywood, 2007, ss. 16-17). W ujęciu Heywooda zarówno idee (jako zbiór), jak i ideologie są zbliżone ${ }^{4}$. Badać ideologię - według Heywooda - „to zajmować się zarazem analizą treści myśli politycznej, interesować się ideami, doktrynami i teoriami, które rozwijały się dzięki i w ramach rozmaitych tradycji ideologicznych". W innej definicji ideologii tym mianem określana jest filozofia polityczna, w której elementy teoretyczne przeplatają się często z praktycznymi, tworząc system ideowo-aksjologiczny, którego celem jest nie tylko opisanie rzeczywistości, ale także jej przekształcanie (Bernacki, 2007, s. 9). Zasadniczo więc w obu definicjach uwypuklony jest praktyczny element ideologii, odnoszący się do zmian, do jakich ma ona doprowadzić. Rodzi się tu kolejne pytanie: jaka jest relacja między ideologią, doktryną ${ }^{5}$ i myślą polityczną? W Słowniku

2 Tradycje szkoły kontynuują współcześnie tacy badacze, jak: Stanisław Borzym, Marcin Król, Paweł Śpiewak, Andrzej Waśkiewicz, Andrzej Mencwel, Dariusz Gawin, Piotr Laskowski, Karolina Wigura. Zob. (Wigura, 2019, ss. 40-41).

Idea (z greckiego idein - wiedzieć) rozumiana jako pojęcie, jakie tworzy umysł w odniesieniu do czegoś. Idea ma charakter intelektualny, co odróżnia ją od zwykłego uczucia. Dyskusje filozoficzne toczą się wokół natury idei. Zob. (Didier, 1992, s. 137; Olszewski, 2015, ss. 153-159).

4 Autor zauważył, że nie ma jednej definicji ideologii.

5 Doktryna (z łac. doctrina - nauka) rozumiana jako termin wieloznaczny, często używany dla określenia całokształtu twierdzeń, przekonań; ma również pejoratywne znaczenie jako dogmatyczne zasady i teorie. 
historii doktryn politycznych zauważono, że część sporów narasta wokół przedmiotu doktryny, wiąże się z jej relacją do innych terminów, takich jak idea, ideologia, program polityczny, myśl polityczna. Próby hierarchizacji lub innego uszeregowania tych terminów, poszukiwania wzajemnego ich stosunku były podejmowane w literaturze przedmiotu niejednokrotnie, nie przyniosły jednak powszechnej zgody ani co do ich miejsca, ani definicji. „Na ogół jednak uważa się, że pod względem stopnia szczegółowości i usystematyzowania poglądów doktryna zajmuje miejsce poniżej idei i ideologii, będąc swoistym systemem normatywnym wartości i wymienionych lub afirmowanych przez ideologie, ich uszczegółowieniem i uporządkowaniem. W ten sposób doktryna stałaby powyżej programu politycznego, przenoszącego jej założenia na grunt praktycznego działania" (Stownik historii..., 1999, s. 67). Opisując relacje między doktryną polityczną a myślą polityczną, zauważono, że istnieją dwie odmienne tendencje. Jedna mówi o tym, że różny jest przedmiot zainteresowania doktryny i myśli politycznej - doktryna to więc zwarty system poglądów politycznych, a myśl to niemal każda refleksja polityczna. $\mathrm{W}$ drugim ujęciu istnieją odmienne pola badawcze: myśl jest bliższa historii, a doktryna prawu (Słownik historii..., 1999, s. 67). Z kolei nestor wśród badaczy doktryn politycznych Roman Tokarczyk uznał, że doktryną polityczną są „,naukowo ujęte różne formy myśli politycznej - idei, ideologii, filozofii i teorii, które mogą być wykorzystywane przez ruchy polityczne jako programy ich działania" (Tokarczyk, 2010, s. 19).

Czy można zająć odmienne stanowisko? Zdaniem autorów idee polityczne łączą się, tworząc coś, co nie ma konkretnych znamion ideologii, ale jest już bardziej uporządkowane niż idee polityczne - tym czymś jest właśnie myśl polityczna. Czym więc różni się myśl polityczna od ideologii? Według jednej ze współczesnych definicji ideologia ${ }^{6}$ to całościowy pogląd na świat, posługujący

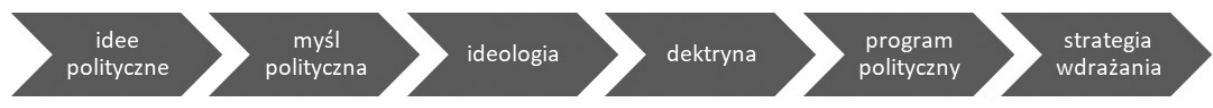

Rys. 1. Konceptualizacja w ujęciu linearnym etapów myślenia politycznego Źródło: opracowanie własne autorów.

6 Jak słusznie zauważał jeszcze w latach osiemdziesiątych Franciszek Ryszka, specjaliści nauk społecznych terminowi ideologia nadają przynajmniej kilkadziesiąt znaczeń. Zob. (Ryszka, 1984, s. 160). 
się polityką do jego urzeczywistnienia (Wielomski, 2007, ss. 129-132)ำ. Myśl polityczna zaś nie ma charakteru praktycznego.

\section{O METODACH I TECHNIKACH BADAŃ MYŚLI POLITYCZNEJ}

O wiele poważniejsze konsekwencje niż brak definicji myśli politycznej implikuje brak standardów badań. Powoduje to, że liczne prace mają charakter deskryptywny czy wręcz są pozbawione analizy. Można też zgodzić się z opinią, że standardy badań są zależne od definiowania myśli politycznej. Najpełniej swoje propozycje w tym zakresie przedstawili Waldemar Paruch i Konrad Jajecznik. Zaproponowali oni prowadzenie zarówno badań jakościowych, jak i ilościowych. Istotne jest przy tym uwzględnienie trzech skal, wyróżnionych pod względem przedmiotu pomiaru: kontinuum - badającej stopień natężenia wybranej cechy w postaci wartości 0 + nieskończoność; spektrum - badającej występowanie przeciwstawnych wartości +1 i -1 ; diada, za pomocą której bada się wartości aksjologiczne oraz dystans między wartościami niepowiązanymi treściowo (Jajecznik, 2006, ss. 255-259). Istotne byłoby chociażby badanie frekwencyjności wyrazów. Przykładowo, jak wskazała Ewa Maj, w pracach Romana Dmowskiego dominowała kategoria naród (Maj, 2020, s. 34). Kwestionariusze formułowanych pytań powinny mieć charakter specyficzny, uniwersalny. Warto też zwrócić uwagę na zasadność tworzenia typów idealnych według Maxa Webera. Patryk Tomaszewski w analizie kategorii bezpieczeństwo energetyczne (Tomaszewski, 2018, ss. 119-124) w koncepcjach polskich środowisk politycznych posłużył się narzędziem badawczym w postaci eksploracji danych tekstowych za pomocą metody text mining. Z kolei Stanisław Filipowicz zalecał koncentrowanie się przede wszystkim na badaniu sensu wypowiedzi. Nie chodzi o „spekulowanie na temat związków pomiędzy ideami i rzeczywistością", ponieważ oznaczałoby to „popadanie w manierę” (Filipowicz, 2001, s. 6). Należy też uwzględnić uwa-

7 Podobnie ideologię zdefiniował Roger Scruton: „Każda usystematyzowana i całościowa doktryna polityczna, chcąca uchodzić za pełną i znajdującą uniwersalne zastosowanie teoria człowieka i społeczeństwa, z której można wyprowadzić program polityczny”. Zob. (Scruton, 2002, s. 134).

8 W Europie Zachodniej już od kilkunastu lat przeprowadza się analizy kategorii politycznych, obecnie przy zastosowaniu Text mining (eksploracja tekstu) - czyli metody eksploracji danych służących do wydobywania danych z tekstu i ich późniejszej obróbki. Ze względu m.in. na fleksyjność języka polskiego metoda ta w Polsce jest stosowana stosunkowo rzadko w kontekście badań nad myślą polityczną. 
runkowania wypowiedzi, w tym kontekst i specyfikę myśli danego autora czy badacza (Mikołajczyk, 2015, ss. 70-71). Związane z tym tokiem interpretacji obawy zwerbalizował natomiast Michał Jaskólski, pisząc: „żywię obawy związane z semantyką, ponieważ owe projekcje autorów budowane były i są ze słów, których znaczenie podążało za zmienną rzeczywistością, nie wspominając o częstej ich wieloznaczności, co w przełożeniu na politykę zmieniało ich pierwotny sens" (Jaskólski, 2016, s. 49).

Konsekwencją stosowania różnych metod i technik badawczych jest widoczne w opracowaniach zróżnicowanie kryteriów typologii myśli politycznej. Obecne w politologii ujęcie linearne lewica - centrum - prawica zostało wzbogacone o propozycję Romana Bäckera. Zaproponował on trzy sposoby podziału typów myśli politycznej. Pierwszy - według kryteriów logiki emanatystycznej i analitycznej. Drugi - odnoszący się do typologii kultur politycznych; do znanego podziału Binghama Powella i Gabriela Almonda badacz dodał czwarty typ, który określił jako totalitarny, oparty na koncepcji nowego człowieka. Trzeci podział powstał w efekcie adaptacji analiz Vilfredo Pareto, dotyczących sposobów komunikowania się między ludźmi. W konsekwencji Bäcker wyróżnił myślenie naukowe, myślenie trybalne, plemienne oraz gnozę polityczną (Bäcker, 2003, ss. 107-112). Należy dodać, że myśl polityczna często analizowana jest w ujęciu podmiotowym, np. danej partii politycznej czy środowiska politycznego. Przykładowo można wskazać pracę poświęconą myśli Ligi Polskich Rodzin (Koziełło, 2017) czy obozu narodowego (Smolik, 2017). W konsekwencji liczni autorzy podkreślają potrzebę opracowania syntezy polskiej myśli politycznej.

Należy zauważyć, że duży konsensus w polskich badaniach związany jest z określeniem źródeł myśli badawczej, a więc analizowanego materiału empirycznego. Najczęściej wskazuje się na trzy rodzaje podmiotów wytwarzających dokumentację wykorzystywaną w badaniach: indywidualne - politycy, publicyści, naukowcy; zbiorowe - partie polityczne, organizacje itp; kratologiczne - organy władzy (Sanecka-Tyczyńska, 2018, ss. 24-25). 


\section{BADANIA MYŚLI POLITYCZNEJ W KRAJACH ANGLOSASKICH - REKONESANS}

Przyglądając się badaniom z zakresu myśli politycznej prowadzonym w krajach anglosaskich, można dostrzec, że odnoszą się one przede wszystkim do zagadnień związanych z jej filozoficznymi aspektami lub też - w ujęciu problemowym - do zagadnień ustrojowych państwa, jak demokracja czy konstytucjonalizm.

Bez wątpienia badacze anglosascy mają również problem $z$ delimitacją pojęcia myśli politycznej czy ideologii. Jednak w pracach dotyczących teorii polityki czy też w opracowaniach z zakresu metodologii badań częściej pojawia się nawiązanie do ideologii, a badania nad nią przypominają - w odniesieniu do polskich warunków - badania myśli politycznej. Oznacza to, że analizowane są również takie zagadnienia, jak np. koncepcje polityki zagranicznej prezentowane przez danego polityka czy też ewolucja poglądów politycznych partii. W opracowaniu Peri Robertsa i Peter Sutcha An Introduction to Political Thought. A Conceptual Toolkit myśl polityczna została potraktowana jako synonim teorii i filozofii politycznej. Takie podejście odnosi się do tej części nauk politycznych, która dotyczy wartości, idei, norm i pojęć (Roberts, Sutch, 2012, s. 19). Autorzy omówili koncepcje głównych myślicieli politycznych od Platona do Rawlsa oraz odrębnie takie zagadnienia, jak wolność, sprawiedliwość, autonomia.

Zdaniem Jonathana Leadera Maynarda w Wielkiej Brytanii nie ma jednego podejścia do myśli politycznej: można ją traktować jako kategorię nadrzędną wobec ideologii i doktryn, badacze uznają bowiem, że od myśli biorą się idee. Inne podejście, związane $\mathrm{z}$ historią idei, sytuuje myśl polityczną w kontekście badań nad dziełami filozoficznymi. Według Maynarda prowadzone są też badania bliższe naszemu rozumieniu myśli politycznej (chodzi o szerokie ujęcie, np. polityka zagraniczna w koncepcjach liberałów itp.). Poza tym autor wskazał, że w Wielkiej Brytanii również trwa dyskusja na temat metod badawczych wykorzystywanych w badaniach przede wszystkim nad ideologiami'.

Podobnie jak w Polsce pewne problemy rodzi samo dookreślenie terminu ideologia. Można się jednak spotkać z dominującym podejściem funkcjonalnym, według którego ważne jest wyjaśnienie, co rozumie się przez pojęcie ideologii. Badacz, tworząc siatkę pojęciową, powinien zwrócić przede wszystkim uwagę, aby definicje (mowa o przypadkach braku jednej konkretnej definicji) były uzasadnione zgodnie $\mathrm{z}$ tym, jak funkcjonalnie przydatne będą do prowadzonych

9 Wymiana maili z naukowcem w zbiorach autora. 
badań (Maynard, 2017). Badacze proponują dokonywanie analizy ideologii - nie oznacza to jej opisu, wymieniania enumeratywnie jej składowych, ale przede wszystkim sprawdzenie, jak myślą ludzie. Oczywiście to odniesienie dotyczy badania ideologii współczesnych, w którym można pozyskiwać materiał empiryczny. Aby powiedzieć coś na temat ideologii, musimy się czegoś dowiedzieć w kontekście rzeczywistej treści danej ideologii. Zdaniem Jonathana Leadera Maynarda badacze zakładają, że treść ideologiczna jest im znana i nieskomplikowana, sprowadzając ją do etykiety lub punktu na kilkupunktowej skali, np. od „ekstremalnie konserwatywnej” do „ekstremalnie liberalnej” używanej często w USA przy tworzeniu ankiety badania preferencji politycznych respondentów. Według badacza może to być uzasadnione w przypadku pewnych ograniczonych form analizy korelacyjnej w naukach politycznych. W konsekwencji skuteczna analiza ideologiczna wymaga od naukowców zastosowania metod, które faktycznie pozwalają na gromadzenie bogatych danych na temat rzeczywistego myślenia politycznego i poważnego angażowania się w nie (Maynard, 2017). Maynard zaproponował triangulację kilku technik: wnioskowanie behawioralne - jak jednostki zachowują się w świetle ideologii; analiza tekstów (wszelkiego rodzaju komunikatów); bezpośrednie pozyskiwanie informacji poprzez badania jakościowe (wywiady) oraz ilościowe pomiary na skalach; metody neuronaukowe badanie procesów neurologicznych w mózgu człowieka i szerzej - w układzie nerwowym. Analiza ideologiczna, którą można obronić, polega na interpretowaniu tekstów (również wywiadów) i szukaniu odpowiedzi poprzez rygorystyczne i dokładne zadawanie pytań, co pozwala na wyciągnięcie wiarygodnych wniosków na temat myślenia na podstawie zawartych w nich informacji, w tym niewerbalnych przypadków komunikacji (Maynard, 2017, s. 13; Maynard, 2013, ss. 299-327). Myśl polityczna może być badana również w ujęciu konkretnych teorii, np. neomarksistowskiej, postmodernistycznej. Badania myśli politycznej są prowadzone w kontekście teorii politycznej, która podejmuje próby kategoryzacji takich pojęć, jak wolność, demokracja, równość, sprawiedliwość (List, L. Valentin, s. 6). Punktem odniesienia dla wielu badaczy jest koncepcja Leo Straussa. Po pierwsze uważał on, że pisarze polityczni ukrywali często swoje poglądy. W tekście pozostawiali jednak wskazówki, jak należałoby dokonać interpretacji. Po drugie wzywał do specyficznej „,rozmowy z poprzednikami”, czyli podejmowania samodzielnej próby dociekań w duchu Sokratesa. Po trzecie zaś mniejszą wagę przywiązywał do kontekstu wypowiedzi, bagatelizując okoliczności historyczne. Szczególnym zainteresowaniem w Polsce cieszy się Cambridge School, której reprezentatywnym przedstawicielem jest Quentin Skinner. Główne założenia 
tego nurtu jeden $\mathrm{z}$ polskich interpretatorów przedstawił następująco: $\mathrm{w}$ sferze polityki nie ma uniwersalnych prawd, w konsekwencji wszystkie wypowiedzi mają lokalny i historyczny kontekst; wymagana jest koncentracja na tym, jaką myśl autor chciał wyrazić (Grygieńć, 2016, 185-206).

Inne podejście, utrzymane w klasycznej specyfice historii idei, koncentruje się na istotnych motywach i tematach oraz na ich wewnętrznej logice niezależnie od kontekstu. Coraz większą popularnością także w Polsce cieszą się rozważania w ramach Culture Studies. Według tego podejścia nie bada się dziejów idei dla jej zrozumienia, ważne są przede wszystkim dyfuzje, rozprzestrzenianie idei w społeczeństwie, zainteresowania, jakie budzą, rola i funkcja idei w dyskursach publicznych.

Wykorzystując metodę randomizacji, dokonano przeglądu stron internetowych poświęconych badaniom myśli politycznej. Nawet pobieżna ich analiza dowodzi zasadności opinii wcześniej zaprezentowanej. W katalogu „Routledge Studies in Social nad Political Thought” znaleziono monografie oparte na różnych paradygmatach badawczych, których autorzy eksplorują szerokie pole badawcze. Jedną z ostatnio opublikowanych prac jest książka From Hitler to Codreanu. The Ideologies of Fascist Leaders, inne opracowanie to np. The Intellectual Origins of Modernity. W 2018 roku na uwagę zasługiwała publikacja Enlightenment in Scotland and French. Studies in Political Thought. Uniwersytet w Pensylwanii polecał w 2020 roku opracowanie wydane w ramach serii „Historia Intelektualna Współczesności”: The Anthropological Turn. French Political Thought after 1968. Na stronie czasopisma „Cognition” można odszukać informację, że jeden z jego monograficznych numerów został poświęcony The Cognitive Science of Political Thought. Z kolei International Conference for the Study of Political Thought, organizacja badawcza założona w Kanadzie w 1967 roku, informuje, że tematem przewodnim w 2021 roku będzie „Democratic Representation. Acts, Aesthetics, Institutions”. W czasopiśmie „American Political Thought: A Journal of Ideas, Institutions and Culture", wychodzącym od 2012 roku, można znaleźć artykuły zbliżone tematyką do niektórych polskich publikacji z zakresu myśli politycznej. Zgodnie z założeniem twórców czasopisma wypełnia ono lukę między badaniami historycznymi, empirycznymi i teoretycznymi, jest poświęcone wyłącznie badaniu amerykańskiej tradycji politycznej. W interdyscyplinarnym zakresie obejmuje badania prowadzone przez politologów, historyków, literaturoznawców, ekonomistów i filozofów, którzy analizują podstawy i tradycję polityczną takich pojęć, jak demokracja, konstytucjonalizm, równość, wolność, obywatelstwo, tożsamość polityczna i rola państwa (American Political Thought). Natomiast 
w bardzo cenionym przez badaczy w Wielkiej Brytanii, ukazującym się od 1980 roku, piśmie „History of Political Thought” publikowane były artykuły odnoszące się do refleksji, którą w Polsce często zajmują się badacze doktryn polityczno-prawnych lub filozofowie polityki. Zgodnie $\mathrm{z}$ informacjami zawartymi na stronie internetowej pisma najwięcej artykułów poświęconych było myśli Platona $(\mathrm{n}=16)$; Hobbesa, Marxa $(\mathrm{n}=13)$; Rousseau $(\mathrm{n}=12)$; Arystotelesa $(\mathrm{n}=9)$ (Description, History of Political Thought).

\section{WNIOSKI}

Tomasz Zarycki i Tomasz Warocz (Warczok, Zarycki, 2016) zwrócili uwagę na fakt, że światowe centra badań naukowych narzucają obowiązujący paradygmat naukowy, wzorce badań oraz metodologię obszarom półperyferyjnym, takim jak Polska. Odpowiadając na globalne wyzwania naukowe, polscy badacze przyjęli dwie strategie, których zwolennicy określają się mianem separatystów i imitatorów. Pierwsza grupa podkreśla specyfikę polskiego rozwoju dziejowego i konieczność zastosowania odrębnych wzorców badań. Druga dąży przede wszystkim do posługiwania się tożsamymi narzędziami, aby po pierwsze - dzięki wykorzystaniu podobnych metod osiągnąć porównywalne wyniki; po drugie umożliwić swoiste „wyjście z cienia”, pozwalające na rozpowszechnienie wyników rodzimych badań; po trzecie wreszcie - spełniać kryteria ewaluacyjne wprowadzone na polskich uczelniach. Nie bez znaczenia jest też fakt, że w naukach społecznych w Polsce od lat dziewięćdziesiątych XX wieku usilnie szuka się własnej tożsamości naukowej, oddzielającej np. nauki o polityce od historii współczesnej czy socjologii, stosunki międzynarodowe od nauk o polityce, a w ostatnich latach poszukuje się tożsamości nauk o bezpieczeństwie niejako w kontrze do nauk o polityce (Siemiątkowski, Tomaszewski, 2018, ss. 13-29).

W zakresie myśli politycznej w Polsce podkreśla się, podobnie jak w krajach Europy Zachodniej, konieczność doprecyzowania pojęć. Akceptowana jest interdyscyplinarność i niezbędność zastosowania ujęcia ilościowego. Jednocześnie pojawiają się postulaty wprowadzenia dorobku polskiej myśli do ogólnoeuropejskiego obiegu (Rzegocki, 2015, ss. 99-108). Wiąże się z tym jeszcze jeden istotny problem. W recenzjach prac podkreśla się niejednokrotnie, że analiza konkretnej doktryny politycznej w Polsce powinna uwzględniać lokalną specyfikę. Siatka pojęciowa konserwatyzmu, a zwłaszcza klasyfikacji różnych nurtów, nie powinna być tworzona wyłącznie na podstawie odniesień np. do klasycznej brytyjskiej czy 
amerykańskiej odmiany. Ważny jest więc problem delimitacji pojęcia polskiej myśli politycznej. Ramę klasyfikacyjną wyznacza dla wielu autorów klasyczny antagonizm polskie - niepolskie (Góra-Szopiński, 2016, s. 56). Skrajni reprezentanci polskiej myśli dążyli wręcz do jej puryfikacji. Badacze myśli politycznej wskazują jednak często na inspiracje zewnętrzne w koncepcjach głoszonych na ziemiach polskich. Wynika stąd logiczny wniosek, że zarówno twórcy, jak i badacze myśli politycznej odnosili się do idei powstałych w europejskim kręgu kulturowym.

Analizując treść artykułów naukowych badaczy polskich i anglosaskich, można dostrzec podobieństwo poruszanych zagadnień. Również metody badawcze są często implementowane, co nie oznacza braku próby własnych ujęć.

Nawiązując do postawionych we wprowadzeniu dwóch hipotez badawczych, autorzy uważają, że współcześnie w Polsce widoczna jest adaptacja anglosaskich rozwiązań metodologicznych, jednak należy podkreślić, że na podstawie analizy treści kilku czasopism poświęconych myśli politycznej w USA i Wielkiej Brytanii nie da się stwierdzić, że w tych krajach istnieje jeden model badań myśli politycznej czy też ideologii. Poza tym nie ma wyraźnego oddzielenia badań myśli politycznej od badań ideologii czy doktryn politycznych. Część badań jest zbliżona do tych uprawianych w Polsce. Autorzy przeanalizowali treść artykułów zamieszczonych na łamach kwartalnika „American Political Thought: A Journal of Ideas, Institutions and Culture" w latach 2018-2020. Część publikowanych tekstów trudno jednoznacznie zakwalifikować. Z pewnym uproszczeniem można powiedzieć, że większość z nich odnosi się do ustroju i systemu politycznego, do refleksji nad demokracją czy też konstytucją w poglądach polityków, twórców myśli politycznej, a nawet pisarzy. Znacznie częściej problemami, które w Polsce poruszają badacze myśli politycznej, w Wielkiej Brytanii zajmują się twórcy czasopisma „Journal of Political Ideologies”. Pismo jest poświęcone analizie ideologii politycznej w jej aspektach teoretycznych i koncepcyjnych oraz badaniu natury i roli poszczególnych przejawów i praktyk ideologicznych. Przeglądając zamieszczone w nim artykuły, można zauważyć, że zawierają one analizy przypominające badania polskich naukowców. W piśmie znajdziemy różnorodne artykuły poświęcone nie tylko filozofom polityki, ale też poszczególnym zagadnieniom związanym z programami politycznymi. Można wymienić chociażby takie artykuły, jak: Strangled at birth: the One Nation ideology of Theresa May (Hickson, Page, Williams, 2020), The local dimension in the degrowth literature. A critical discussion (Mocca, 2020), Ideology as blocked mourning: Greek national identity in times of economic crisis and austerity (Glynos, Voutyras, 2016). 
Odnosząc się do drugiej hipotezy, można stwierdzić, że mimo prób badaczy myśli politycznej w Polsce nie udało się stworzyć zamkniętego katalogu tematów badawczych z obszaru myśli politycznej, a także wypracować katalogu metod badawczych. Co więcej, eksplorowane pole badawcze się rozszerza, a myśl polityczna zaczyna obejmować obszary szczegółowe, jak np. Polityka wschodnia Polski w myśli politycznej partii Prawo i Sprawiedliwość (lata 2005-2007); Wizja państwa w myśli politycznej Unii Wolności, International security in the election programmes of Civic Platform between 2001 and 2015 (Chojan, 2016;Szczepański, 2012; Tomaszewski, 2015).

\section{BiBLIOGRAFIA:}

American Political Thought, Pobrane z: https://www.journals.uchicago.edu/toc/apt/ current.

Bachryj-Krzywaźnia, M. (2016). Filozoficzne ramy i przesłanki zróżnicowania podejścia interpretacjonistycznego. Wrocławskie Studia Politologiczne, 21, 7-23. DOI: 10.19195/1643-0328.21.1.

Bäcker, R. (2003). Nie - tradycyjna typologia myśli politycznej. W: R. Bäcker, J. Marszałek-Kawa, J. Modrzyńska (red.). Zrozumieć politykę. Główne problemy teorii polityki i współczesnej myśli politycznej. Toruń: Wydawnictwo Adam Marszałek.

Bäcker, R. (2017). Myśl polityczna jako przedmiot badań. W: J. Silezin, R. Wiszniowski, M. Alberska (red.). Od historii myśli do praktyki politycznej. Księga dedykowana profesorowi Jerzemu Juchnowskiemu z okazji 40-lecia pracy naukowej. Toruń: Wydawnictwo Adam Marszałek.

Bajer, J. (2012). Badania porównawcze w politologii. Zagadnienia metodologiczne. Studia Politicae Universitatis Silesiensis, 8, 15-48.

Berlin, I. (1991). Dwie koncepcje wolności i inne eseje. Warszawa: Wydawnictwo Res Publica.

Bernacki, W. (2007) Ideologia. W: Słownik historii doktryn politycznych. t. 3. Warszawa: Wydawnictwo Sejmowe.

Chojan, A. (2016). Polityka wschodnia Polski w myśli politycznej partii Prawo i Sprawiedliwość (lata 2005-2007). Rocznik Instytutu Europy Środkowo-Wschodniej, 5, 301-314.

Chojnicka, K., Olszewski, H. (2004). Historia doktryn politycznych i prawnych. Podręcznik akademicki. Poznań: Ars boni et aequi.

Description, History of Political Thought, Pobrane z: https://www.imprint.co.uk/ product/hpt/.

Didier, J. (1992). Siłownik filozofii. Warszawa: Wydawnictwo Książnica.

Glynos, J., Voutyras S. (2016). Ideology as blocked mourning: Greek national identity in times of economic crisis and austerity. Journal of Political Ideologies, 21(3), https:// www.tandfonline.com/doi/full/10.1080/13569317.2016.1207300. 
Góra-Szopiński, A. (2016). Odwaga uniwersalizmu. W kwestii delimitacji polskiej myśli politycznej. W: W kręgu iluzji i realiów. Oblicza polskiej myśli politycznej w XX-XXI wieku. Studia i szkice pod red. G. Radomskiego, M. Strzeleckiego, P. Tomaszewskiego, Toruń 2016.

Grygieńć, J. (2016). Rekonstrukcja intencji czy dekonstrukcja ideologii? Praktyczne konsekwencje kontesktualizmu metodologicznego Quentina Skinnera. W: J. Grygieńć (red.). Quentin Skinner. Metoda historyczna i wolność republikańska. Toruń: Wydawnictwo Uniwersytetu Mikołaja Kopernika.

Heywood, A. (2007). Ideologie polityczne. Wprowadzenie. Warszawa: Wydawnictwo Naukowe PWN.

Hickson, K., R. Page \& B. Williams. (2020). Strangled at birth: the One Nation ideology of Theresa May. Journal of Political Ideologies, 25(3) https://www.tandfonline.com/ doi/full/10.1080/13569317.2020.1773074.

Jachymek, J. (1982). Myśl polityczna Polskiego Stronnictwa Ludowego Wyzwolenie 1918-1931, Lublin: Uniwersytet Marii Curie-Skłodowskiej.

Jajecznik, K. (2006). Myśl polityczna próba standaryzacji badan. Rocznik Nauk Politycznych, 9, 255-270.

Jaskólski, M. (2016). Proteuszowy świat myśli politycznej. Studia nad Autorytaryzmem $i$ Totalitaryzmem, 4, 45-55, DOI: 10.19195/2300-7249.38.4.4.

Klementewicz, T. (2013). Politolog w labiryncie paradygmatów - pułapki eklektyzmu. W: B. Krauz-Mozer, P. Ścigaj (red.). Podejścia badawcze i metodologie $w$ nauce o polityce. Kraków: Księgarnia akademicka.

Koepke, I. (2019). Filozofia polityki Andrzeja Walickiego. Toruń: Wydawnictwo Uniwersytetu Mikołaja Kopernika.

Kornaś, J. (1995). Naród i państwo w myśli politycznej Związku Ludowo-Narodowego. Kraków: Akademia Ekonomiczna.

Koziełło, T. (2017). Myśl polityczna Ligi Polskich Rodzin (2001-2009). Narodowa wizja państwa, społeczeństwa i polityki. Rzeszów: Wydawnictwo Uniwersytetu Rzeszowskiego.

Król, M. (1998). Historia myśli politycznej. Od Machiavellego po czasy współczesne. Gdańsk: Wydawnictwo Arche.

Król, M. (2008). Filozofia polityczna. Kraków: Wydawnictwo Znak.

Kucharczyk, G. (2009). Polska myśl polityczna po roku 1939. Dębogóra: Wydawnictwo Dębogóra.

Kulesza, W. T. (1996). Ideologie naszych czasów. Warszawa: Wydawnictwa Szkolne i Pedagogiczne.

List, Ch., Valentin, L. The Methodology of Political Theory. Pobrane z: https://personal. lse.ac.uk/list/PDF-files/MethodologyPoliticalTheory.pdf.

Maj, E. (2000). Związek Ludowo-Narodowy 1919-1928. Studium z dziejów myśli politycznej, Lublin: Wydawnictwo Uniwersytetu Marii Curie-Skłodowskiej.

Maj, E. (2020). O badaniu myśli politycznej Narodowej Demokracji do roku 1939. Wybrane zagadnienia. Myśl Polityczna, 1, 35-37. 
Maj, E., A. Wójcik. (2008). Wstęp. W: E. Maj, A. Wójcik (red.). Myśl polityczna w Polsce po 1989 roku. Wybrane nurty ideowe. Lublin: Wydawnictwo Uniwersytetu Marii Curie-Skłodowskiej.

Maynard, J. L. (2017). Ideological Analysis, in Adrian Blau. W: Methods in Analytical Political Theory. Cambridge: Cambridge University Press.

Maynard, J. L. (2013). A Map of the Field of Ideological Analysis. Journal of Political Ideologies, 18(3), 299-327.

Mikołajczyk, M. (2015). „Kredowe koło” myśliciela badacza. O paradygmatach (kontekście i perspektywie postrzegania) w badaniach, których przedmiotem jest myśl polityczna. Humanities and Social Science, 3, 69-81.

Mocca, E. (2020). The local dimension in the degrowth literature. A critical discussion. Journal of Political Ideologies, 25(1), Pobrane z: https://www.tandfonline.com/doi/ full/10.1080/13569317.2019.1696926.

Myśl polityczna na wygnaniu. Publicyści i politycy polskiej emigracji powojennej. (1995) A. Friszke (red.). Warszawa: Instytut Studiów Politycznych Polskiej Akademii Nauk.

Olszewski, E. (1999). Myśl polityczna. W: W. Sokól, M. Żmigrodzki (red.). Encyklopedia politologii. Kraków: Zakamycze.

Olszewski, E. (2015). Wybrane problemy myśli politycznej (idea, ideologia, doktryna polityczna). W: E. Maj, E. Kirwiel, E. Podgajna (red.). Myśl polityczna w społeczeństwie informacyjnym. Lublin: Wydawnictwo Uniwersytetu Marii Curie-Skłodowskiej.

Opałek, K. (1962). Problemy metodologiczne nauki prawa. Warszawa: Państwowe Wydawnictwo Naukowe.

Paruch, W. (1999). Myśl polityczna- refleksje metodologiczne o pojęciu. Annales Universitatis Marie Curie Skłodowska, sectio K: Politologia, 6, 27-40.

Paruch, W. (2005). Myśl polityczna obozu piłsudczykowskiego 1926-1939. Lublin: Wydawnictwo Uniwersytetu Marii Curie-Skłodowskiej.

Paruch, W. (2006). Myśl polityczna we współczesnej polskiej politologii: modernizacja przedmiotu, strategii i metod badania. W: M. Cichosz, K. Zamorska (red.). Politologia w Polsce: stan i perspektywy. Wrocław: Wydawnictwo Uniwersytetu Wrocławskiego.

Paruch, W. (2009). Kategorie ekonomiczne a zakres pojęcia myśl polityczna - refleksje metodologiczne. W: E. Maj, S. Michałowski, A. Wójcik (red.). Idee-państwo-ludowcy. Ksiega jubileuszowa $z$ okazji 70.rocznicy urodzin profesora Jana Jachymka. Lublin: Wydawnictwo Uniwersytetu Marii Curie-Skłodowskiej.

Paruch, W. (2015). Konsekwencje definiowania myśli politycznej dla kwestionariusza badań politologicznych. Humanitis and Social Science, 1, 157-175.

Pasierb, B. (1996). Wstęp. W: B. Pasierb, K. A. Paszkiewicz (red.). Współczesna polska myśl polityczna. Wybrane ośrodki, koncepcje, system wartości. Wrocław: Wydawnictwo Uniwersytetu Wrocławskiego.

Paszkowski, M. (2015). Specyfika badań politologicznych nad myślą polityczną w zakresie bezpieczeństwa energetycznego państwa. Humanities and Social Since, 2, 99-109, DOI: $10.7862 /$ rz.2015.hss.22. 
Ponczek, E. (2015). Style i wzorce badań myśli politycznej: od powierzchownej prezentacji do dogłębności oglądu nomologiczno-eksplanacyjnego. Humanities and social science, 3, 117-135, DOI: 10.7862/rz.2015.hss.38.

Roberts, P., Sutch P. (2012). An Introduction to Political Thought. A Conceptual Toolkit. Edydnburg: Edinburgh University Press.

Rogowski, W. (2013). Dylematy liberalizmu. Wokół myślenia politycznego Józefa Tischnera. Toruń: Dom Wydawniczy Duet.

Ryszka, F. (1984). Nauka o polityce. Rozważania metodologiczne. Warszawa: Państwowe Wydawnictwo Naukowe.

Rzegocki, A. (2015). O roli polskiej myśli politycznej we współczesnej Europie. W: I. Barwicka-Tylek, A. Czarnecka, M. Jaskólski, J. Malczewski (red.). Myślenie o polityce i prawie. Przedmiot, metoda, praktyka. Warszawa: Wydawnictwo Wolters Kluwer.

Sanecka-Tyczyńska, J. (2018). Racja stanu we współczesnej polskiej myśli politycznej 2001-2015. Lublin: Wydawnictwo Uniwersytetu Marii Curie-Skłodowskiej.

Ścigaj, P., Bukowski, M. (2012). Zastosowanie analizy zawartości w badaniach politologicznych. Athenaeum. Polskie Studia Politologiczne, 36, 11-28.

Scruton, R. (2002). Słownik myśli politycznej. Poznań: Wydawnictwo Zysk i s-ka.

Seidler, G. (1974). Przedmarksowska myśl polityczna. Kraków: Wydawnictwo Literackie.

Siemiątkowski, P., Tomaszewski, P. (2018). Obszar, problematyka i interdyscyplinarność badań nad bezpieczeństwem w polskim dyskursie naukowym. W: Z. Polcikiewicz, P. Siemiątkowski, P. Tomaszewski (red.). Współczesne wyzwania polityki bezpieczeństwa państwa. Toruń: Wydawnictwo TNOiK „Dom Organizatora”. DOI: 10.5281/ zenodo.3244158.

Skarzyński, R. (1990). Intelektualiści a ideologia: myśl polityczna jako przedmiot badań politologa. Studia Nauk Politycznych, 4-6, 7-32.

Skarzyński, R. (1992). Historia myśli politycznej w ujęciu politologicznym. Studia Polityczne 1992, 1, 107-119.

Skarzyński, R. (2004). Podstawowe typy myśli politycznej. Studia Nauk Politycznych, 1. Śliwa, M. (1993). Polska myśl polityczna w I połowie XX wieku. Wrocław: Zakład Narodowy im. Ossolińskich.

Smolik, B. (2017). Naród we współczesnej polskiej myśli nacjonalistycznej. Problematyka narodu w ujęciu głównych nurtów polskiego nacjonalizmu w latach 1989-2004. Kraków: Księgarnia Akademicka.

Sobolewski, M. (1976). Niektóre problemy teorii i metodologii historii doktryn politycznych. Historyka, 6, 3-17.

Sylwestrzak, A. (1994). Historia doktryn politycznych i prawnych. Warszawa: Wydawnictwo LexisNexis.

Szczepaniak, K., (2012). Zastosowanie analizy treści w badaniach artykułów prasowych - refleksje metodologiczne. Acta Universitatis Lodziensis. Folia Socjologica, $42,83-112$.

Szczepański, D. (2012). Wizja państwa w myśli politycznej Unii Wolności. Polityka i Społeczeństwo, 10, 151-159. 
Tokarczyk, R. (2010). Współczesne doktryny polityczne. Warszawa: Wydawnictwo Wolters Kluwer.

Tomaszewski, P. (2015). International security in the election programmes of Civic Platform between 2001 and 2015. Torun Internacional Studies, 8, 135-147, http:// dx.doi.org/10.12775/TIS.2015.012.

Tomaszewski, P. (2018). Bezpieczeństwo energetyczne współczesnej Polski w koncepcjach politycznych środowisk politycznych. W: A. Czwołek, P. Siemiątkowski, P. Tomaszewski (red.). Bezpieczeństwo energetyczne państwa. Toruń: Wydawnictwo TNOiK „Dom Organizatora”.

Warczok, T., Zarycki, T. (2016). Gra peryferyjna. Polska politologia w globalnym polu nauk społecznych. Warszawa: Wydawnictwo Naukowe Scholar.

Wielomski, A. (2007). Ideologia. W: J. Bartyzel, B. Szlachta, A. Wielomski (red.). Encyklopedia polityczna. t. I. Radom: Wydawnictwo Polwen.

Wigura, K. (2019). Wynalazek nowoczesnego serca. Filozoficzne źródła współczesnego myślenia o emocjach. Warszawa: Wydawnictwo Szchlar.

Woźniak, W. (2015). Myśl polityczna - historia idei - filozofia polityczna: relacje, interpretacje. W: E. Maj, E. Kirwiel, E. Podgajna (red.). Myśl polityczna w społeczeństwie informacyjnym. Lublin: Wydawnictwo Uniwersytetu Marii Curie-Skłodowskiej.

Woźniak, W. (2017). Programy polskich partii politycznych jako materiał empiryczny w badaniach dyskursu politycznego. Środkowoeuropejskie Studia Polityczne, 2, 41-58, DOI 10.14746/ssp.2017.2.3.

Zieliński, H. (1958). O potrzebie i trudnościach badania dziejów polskiej myśli politycznej W: H. Zieliński (red.). Polska myśl polityczna XIX i XX wieku. Polska i jej sąsiedzi. t. 1. Wrocław: Polska Akademia Nauk-Zakład Narodowy im. Ossolińskich.

Żychowski, M. (1976). Polska myśl socjalistyczna XIX i XX wieku (do 1918). Warszawa: Państwowe Wydawnictwo Naukowe. 